\title{
Conservative policy under Hague
}

\author{
Peter Dorey
}

The Tories have published any number of pre-manifesto documents, only to rip them up and start all over again in the manner of a panic-stricken student sitting an exam that he knows he will fail. ${ }^{1}$

The Conservative Party encountered considerable difficulty in crafting a coherent package of policies once in opposition after the 1997 election defeat. Much of this difficulty derived from the ideological uncertainty which afflicted the Conservative Party during this period, as discussed in the previous chapter. Conservatives were uncertain as to whether their response ought to be a more vigorous advocacy of Thatcherism, thereby placing 'clear blue water' between them and New Labour, or whether they should embrace a more 'compassionate conservatism', in order to recapture the One Nation terrain that the party occupied so successfully until the 1970s. In the context of such uncertainty, Conservative policies often lacked coherence, clarity and consistency.

These problems were compounded by differences of interpretation concerning the significance of New Labour's 1997 election success. Whilst the proponents of a more 'compassionate conservatism' were inclined to view the Blair government's victory as reflective of a definite and significant change of public mood after eighteen years of 'permanent revolution', the continued adherents of Thatcherism maintained the view that New Labour was all spin and no substance, so that the Blair government's policies and popularity would dissipate once hard choices had to be made, and Labour's policies either proved ineffective or unpopular (or both). The former perspective clearly implied the need for a major rethink of Conservative policy, and a shift back towards the centre ground, whilst the latter view seemed to suggest that rather than panic, and ditch the policies so successfully pursued during the previous eighteen years, the Conservative Party ought to hold its ground, thereby regaining political and electoral support once the New Labour 'project' unravelled, whilst also demonstrating firmness and consistency of both principles and policies.

Consequently, the Conservatives evinced both intra-party disagreement 
over general policy direction, and shifts and U-turns concerning a number of specific polices. This chapter will examine Conservative policies in seven main areas: the economy, 'tax and spend' (including public services), law and order, the family and sexual politics, welfare reform and pensions, asylum seekers, and rural affairs. The vital and vexatious issue of Europe is addressed in Chapter 8.

\section{The economy}

Throughout most of the 1980s successful stewardship of the economy had been the Conservative Party's trump card, and one which was played with devastating effect against Labour in the 1992 election especially. In spite of having presided over two recessions during this period, general elections saw the Conservatives lead the Labour Party by large majorities when opinion polls asked voters who they most trusted to manage the economy. During a period when the nationalized industries were deeply unpopular and government intervention in the economy was widely deemed to be excessive and inimical to entrepreneurial innovation and wealth-creation, the Conservative Party's advocacy of 'rolling back the state', rewarding risk-takers, and reducing inflation, proved highly popular, even though voters were less enamoured with the social consequences (high unemployment, under-funded public services). Thus psephologists during the 1980s developed the notion of 'pocket voting', whereby perceptions of material well-being, and judgements about the economic competence of the political parties, often proved the decisive criteria in shaping the outcome of a general election. The Labour Party might have proffered more popular social policies, but on the all-important issue of economic trust the Conservatives seemed unassailable.

This changed irrevocably on 16 September 1992 ('Black Wednesday'), when Britain was obliged to withdraw from the Exchange Rate Mechanism. Literally overnight, the Conservatives' previous reputation for economic competence was destroyed, and thereafter, right up until the 1997 election (and beyond), the party trailed Labour in the polls, often by 15-25 per cent. Even though the British economy was in relatively good health - hence the Conservatives' poster campaign proclaiming 'Britain's booming; don't let Labour ruin it' - the electorate seemed unwilling to grant the Conservatives much credit or gratitude for this renewed prosperity. Indeed, there seemed to be a tacit view amongst many voters that if the British economy was now booming, it was in spite of, not because of, the Major government's economic policies. Furthermore, the sense of economic well-being actually seemed to have made more voters willing to risk voting Labour (whereas in previous elections, when the economic situation was often rather poor, much of the electorate was inclined to 'cling to nurse, for fear of something worse'). 
Having lost the 1997 election, the Conservatives continued to find it difficult to challenge the trust which New Labour now enjoyed from much of the electorate over successful management of the economy. One reason for this difficulty derives from the extent to which the Labour Party under Tony Blair's leadership has embraced 'the market', and accepted the need to prioritise low inflation and fiscal prudence. Indeed, on many aspects of economic policy, the first Blair government seemed explicitly to adopt many of the measures formerly pursued by the Major government. In this context, the Conservative opposition led by William Hague found it difficult to launch an effective or sustained attack on the Blair government on many economic issues, particularly because strong criticism might have been interpreted as a repudiation of the economic strategy followed by the Conservatives themselves up until $1997 .^{2}$

Previous Conservative oppositions were used to attacking Labour governments for their formal commitment to public ownership and concomitant nationalisation measures, along with their punitive levels of taxation, alleged hostility to enterprise and entrepreneurship, and high levels of public expenditure. However, the Conservatives after May 1997 were perplexed by a Labour government which rejected nationalisation, refused to increase income tax and actually reduced corporation tax, and contemplated further privatisation (as well as private sector involvement in public services via Public-Private Partnerships, and the continued application of Private Finance Initiatives, initiated by the previous Conservative government). The Blair government posed a further problem for the Conservatives by adhering to the outgoing Major administration's public spending plans for the first two years in office. New Labour's stance on such economic issues made it extremely difficult for the Conservatives to attack it, and thereby articulate an alternative Conservative economic policy agenda.

The second reason why the Conservatives found it so difficult to attack the Blair government on economic affairs was that the British economy remained unexpectedly robust throughout Labour's first term of office. Whereas the Conservatives had historically benefited from the tendency for Labour governments to be fatally weakened by economic crises, the Blair government presided over unprecedented (for a Labour government) economic prosperity and stability, which, in turn, enabled it to benefit from 'pocket voting' in the 2001 election, whilst warning voters that their prosperity and the return to near-full employment would be seriously jeopardised by the return of the Conservatives. Even a widely predicted economic down-turn in 1998 failed to materialise, thus further depriving the Conservatives of ammunition with which to attack the government on the issue of economic management.

Admittedly, various Shadow Ministers attacked the government for the rise in interest rates which occurred during 1997 and 1998 (peaking at 7.5 
per cent in the autumn of 1998), claiming that such 'high levels' were deeply damaging to British industry, although from 1999 onwards rates were in the 5 to 6 per cent range, falling further to 4 per cent in early 2002. Also deemed damaging to British industry were the new regulations and additional red tape which Labour ministers imposed on businesses, often in the guise of either employment or environmental protection. Hague's Conservatives also lamented the high value of sterling, which was rendering British exports uncompetitive, yet it was difficult for Conservative critics to proffer credible alternatives in these areas. Quite apart from the fact that interest rates were now set by the (independent) Bank of England's Monetary Policy Committee, the Conservatives themselves had relied heavily on interest rates as a central tool of macro-economic strategy, with the rate often considerably higher than it was under the Blair government. Meanwhile, reducing the value of sterling to aid British exporters implied either devaluation, which would have resulted in a corresponding increase in the cost of imports (and more expensive goods in the shops), and thus a worsening of Britain's balance of payments, or British membership of the European single currency (which would effectively entail devaluation anyway). As these options were clearly anathema to most Conservatives, their criticisms of the government's macro-economic policies were somewhat lacking in credibility and coherence.

Furthermore, on a couple of economic issues, the Conservatives performed U-turns, the most notable of these being the announcement that a future Conservative government would retain the statutory minimum wage introduced by the Blair government. Hitherto, the Conservatives had repeatedly denounced the minimum wage, alleging that it would seriously damage the competitiveness of the British economy and deter inward investment, thereby jeopardising up to one million jobs. However, once the minimum wage, set at $£ 3.60$ per hour, was on the statute book, Michael Portillo (appointed Shadow Chancellor in February 2000, having won a by-election in Kensington and Chelsea in November 1999) announced that it was no longer formally opposed by the Conservative Party, and would thus not be repealed by the Conservatives when next in office. Other economic U-turns performed by Portillo included abandonment of the party's opposition to independence for the Bank of England (the Blair government having made it independent within days of winning the 1997 election), and a pledge that the Conservatives would henceforth accept the pursuit of full employment as a policy objective.

As such, by the time of the 2001 election campaign, Hague's Conservatives were unable to offer little that was distinctive or original in the sphere of macro-economic policy (beyond continued rejection of the euro), their main pledges being to reduce the inflation target from 2.5 per cent to 2 per cent, and further increasing the independence of the Bank of England, coupled with the establishment of a Council of Economic Advisers to offer advice on the 
Chancellor's fiscal policies. Such measures, though, were hardly likely to enthuse disaffected voters or persuade them to return to the Conservative fold.

However, it was over the twin issues of taxation and public expenditure (commonly referred to as 'tax and spend') that Hague's Conservative Party encountered the most difficulties in opposition, to the extent that this particular policy area warrants consideration in its own right.

\section{'Tax and spend'}

The Conservatives' difficulty in challenging the Labour Party's new-found reputation for economic competence and fiscal prudence was compounded by the problems which arose over the twin issues of taxation and public expenditure (commonly referred to as 'tax and spend'). When the Blair government refused to renege on its pledge not to raise income tax rates, the Conservatives found it necessary to switch focus, firstly by pledging further cuts in direct taxation, and secondly by attacking the government's apparent penchant for increasing indirect taxation instead, which the Conservatives labelled 'stealth taxes'. However, whereas taxation had once been a clear vote-winner for the Conservatives, from 1997 onwards the party struggled to reassert its former dominance over Labour on this issue.

In the autumn of 1999, at the party's annual conference, Hague pledged - in accordance with proposals drafted by his then Shadow Chancellor, Francis Maude - that a future Conservative government would reduce taxes as a proportion of GDP, over the lifetime of a Parliament: the much-vaunted 'Tax Guarantee'. However, more prescient Conservatives recognised that cutting taxes as a proportion of GDP might not prove feasible if the economy entered recession, for, in such a situation, higher unemployment would entail lower income tax and National Insurance revenues combined with an unavoidable increase in social security expenditure, thereby leading to a proportional increase in overall taxation vis-à-vis GDP.

This discrepancy was acknowledged more explicitly when Portillo replaced Maude as Shadow Chancellor in February 2000. Recognising that the policy was a hostage to fortune, Portillo suggested that it might be better viewed as an aspiration (rather than a guarantee), which would clearly give a future Conservative government much more flexibility and mean that if taxes did increase the political damage would be rather more limited. Indeed, Hague and Portillo jointly announced in July 2000 that the 'Tax Guarantee' was being abandoned, due to recognition that the Conservatives could not promise categorically than taxes would definitely not rise when the party was next returned to office. ${ }^{3}$

However, the 'tax and spend' issue was never satisfactorily resolved, and, indeed, was to prove uncharacteristically problematic for the Conservatives during the 2001 general election campaign. At the start of the campaign, the 
party promised tax cuts totalling $£ 8$ billion, these to be financed by 'efficiency savings', cutting bureaucracy and further action on social security fraud. However, Labour was able to question whether such savings were genuinely feasible, and would yield the $£ 8$ billion savings necessary to fund the promised Tory tax cuts. Implicit in such criticism was the question of why the Conservatives had not effected these savings during their eighteen years in office up until 1997.

Worse still, though, was the apparent lack of agreement in the Conservative Party over the envisaged level of tax cuts which would be offered following an election victory. Against the official target of $£ 8$ billion, a BBC Newsnight interview on 11 May heard the Conservatives' social security spokesperson David Willetts intimate that $\mathscr{L} 7$ billion might be a more realistic target. Rather more damaging, however, was the claim, three days later, by the Shadow Chief Secretary to the Treasury, Oliver Letwin, that a Conservative government would actually cut taxes by $£ 20$ billion, whereupon Labour gleefully pointed to a $£ 12$ billion 'black hole' in the Tories' 'tax and spend' figures. ${ }^{4}$ Labour also alleged that the Conservatives had a secret tax-cutting agenda which could only be financed by significant cuts in public expenditure, even though the Conservative Party was pledging to match Labour's promised increases on education, health and law and order. Ultimately, it was the Conservative Party which was forced on the defensive over the issue of 'tax and spend' during the 2001 election campaign, with Labour claiming that 'their sums don't add up'. Thus an ICM poll conducted during the election campaign revealed that on the question of which party was most trusted over taxation, Labour led the Conservatives by 34 per cent to 21 per cent (whilst on the issue of economic competence, the corresponding figures were 49 per cent and 29 per cent).

In emphasising tax cuts (albeit with increased spending on key public services), the Conservatives perhaps failed to appreciate the extent to which the British electorate had become more concerned about reviving the country's ailing public services. The public might not have been clamouring for actual increases in taxation, particularly not direct taxation - although countless opinion polls during the previous decade had suggested that a majority of people would be willing to pay higher taxes if the money was spent on improving public services - but there did seem to be a widespread view amongst the electorate that increased investment in such areas as education and health ought to take precedence over further tax cuts. In this respect, the Conservatives appeared to be fighting the battles of yesteryear, seeming to assume that what had been a highly effective strategy in 1992 would reap dividends once again. It was a major miscalculation.

Inextricably linked to the Conservatives' pledge to reduce the overall tax burden during the lifetime of a Parliament was the party's attack on the government for raising indirect taxation. This offered the Conservatives 
scope to claim that New Labour was little different from Old Labour in its instinctive inclination to raise taxes, except that instead of directly taxing people, it was doing so by stealth, via a range of indirect taxes. As such, it was variously claimed, the overall tax burden increased for many people under the Blair government, even if income tax rates themselves had not been raised. Indeed, as the 2001 election approached, the Conservatives could claim that since May 1997, the level of taxation overall had increased from 35.2 per cent to 37.2 per cent of GDP.

What appeared to be a major breakthrough for the Conservatives on the issue of 'stealth taxes' occurred in the guise of the 'fuel protests' in September 2000. These entailed road hauliers and farmers blockading oil refineries in protest at the high levels of duty charged on petrol in Britain. These protests, combined with rapidly ensuing shortages in the shops (as deliveries dwindled, and panic-buying spread), threatened to bring Britain to a complete standstill, and alarmed Labour ministers who fearfully envisaged another 'winter of discontent'.

The petrol protests enabled the Conservatives to claim that the Blair government had finally been exposed over its reliance on raising indirect taxes, and that the British people were finally beginning to revolt over ever-increasing 'stealth taxes'. Although the blockades were in clear breach of anti-trade union legislation introduced by the Conservatives themselves during the 1980 s (involving as they did more than six pickets at the entrances to the oil refineries, whilst also constituting 'secondary picketing'), and would doubtless have been fiercely condemned by the Conservative Party (and pro-Conservative newspapers) if any other group of workers had sought to 'hold the country to ransom' in such a manner, Hague expressed his clear support by describing the fuel protesters as 'fine, upstanding citizens'. ${ }^{5}$ Opinion polls suggested that the 'fuel protests' were also supported by the overwhelming majority of the British public, in spite of any inconvenience they might have experienced, which further heartened Conservatives who now felt that they had found a clear issue with which to 'reconnect' with the electorate.

Against the backdrop of the fuel protests, Hague pledged that a Conservative government would cut fuel duty by 3 p per litre, and was rewarded by a short-lived surge of support in the opinion polls - the Conservatives' first lead over Labour since 'Black Wednesday' in September 1992. This lead swiftly dissipated, though, partly reflecting Labour's apparent success in challenging the viability of Hague's promised 3p per litre reduction in fuel duty, for the question was once again raised about where the money would come from to finance such a cut. It was also suggested that any reduction in fuel duty might simply be cancelled out by the petrol companies raising fuel prices by the same amount, thereby further undermining the initial attractiveness of Hague's pledge on cutting fuel duty; motorists might find themselves paying exactly the same amount on the garage forecourt 
regardless, whilst Conservative ministers found themselves having either to raise taxes elsewhere to cover the reduced fuel tax revenues, or further cutting public expenditure.

With the exception of their short-lived lead in the opinion polls following the fuel protests, the Conservatives found themselves uncharacteristically on the defensive over taxation issues, desperately seeking to wrest the agenda back from the Blair government. Public disquiet over increases in 'stealth taxes' did not translate into anything but the most fleeting popularity for the Conservatives, for every Conservative pledge to reduce indirect taxation was countered by Labour allegations that such tax cuts could only be financed, ultimately, by further reductions in government expenditure, thereby further damaging Britain's ailing public services.

\section{Law and order}

Traditionally another policy area which had seemed inextricably associated with the Conservative Party, and which had so successfully connected with a significant strand of social authoritarianism in British society - particularly during the 'authoritarian populism' of the Thatcher years - law and order was also an issue over which Hague's Conservatives often struggled to re-establish the party's traditional dominance over Labour. This dominance had been successfully challenged during the 1990s, when - as Labour's home affairs spokesperson - Tony Blair had coined the phrase 'tough on crime, tough on the causes of crime', thereby signalling that a Labour government would no longer appear to exonerate criminal activity on the grounds of socio-economic deprivation or disadvantage. In so doing, the Labour Party shifted from a somewhat 'structuralist determinist' account of crime, to a stance which accepted that irrespective of background or environment, an individual still had to be held responsible for criminal acts, even though in the longer term, improving social conditions would continue to play a part in reducing crime. This revised stance on law and order enabled Labour to neutralise the Conservative Party's traditional dominance in this area, making it much more difficult for the Conservatives to depict Labour as 'soft on crime' or of being 'the criminal's friend'.

This is not to say that they did not try, of course, but it did mean that Conservative attacks on the Blair government's law and order record failed to reap the political dividends that had traditionally accrued to the Party on this policy issue. One line of attack which Hague and his Shadow Home Secretaries pursued was to criticise the government for a decline in police numbers, whilst also denouncing the amount of time and effort which police officers (like most other public sector workers) were obliged to expend on paper work and form filling.

The February 1999 publication of the Macpherson Report was also seized 
upon by Hague as part of his attempt at regaining the initiative on law and order. ${ }^{6}$ An inquiry chaired by Sir William Macpherson had been established by the Labour Home Secretary, Jack Straw, in response to disquiet about the manner in which the police had investigated (or, according to critics, failed properly to investigate) the murder of a black teenager, Stephen Lawrence in 1993. The Macpherson Report was indeed critical of the Metropolitan Police's handling of the case, claiming that it was permeated by a culture of 'institutional racism'. Hague subsequently claimed that the Report had seriously damaged morale in the police force, thereby adding to the problems of recruitment and retention. Yoking together the alleged impact of the Report with the volume of paperwork which police officers were apparently overburdened with, William Hague called, at the Conservatives' 1999 conference, for 'more PCs, and less PC [political correctness]'.

Another event which offered the Conservatives an opportunity to seize the initiative on law and order was the high-profile court case of Tony Martin, a Norfolk farmer. Martin had been subject to numerous burglaries and attempted break-ins at his farm - many of which were attributed to gypsies and 'travellers' in the area - and eventually shot dead a sixteen-year-old intruder (himself part of a gypsy family, and who, it was revealed, already had numerous convictions, having been in trouble with the police throughout his teens). Martin was consequently found guilty of murder - rather than manslaughter - and thus sentenced to life imprisonment. This verdict caused a public outcry, and was also widely condemned by many newspapers, due to the sympathy which people felt for Martin; an ordinary person repeatedly the victim of crime, yet himself given a life sentence for having decided to fight back against criminals, and defend his property against yet another break-in: a plucky 'have-a-go hero'.

The Conservative Party, too, depicted the punishment meted out to Martin as a travesty of justice, also subscribing to the view that he was the victim of crime, rather than a criminal himself. As such, Hague made clear his view that the law needed to be reviewed (in spite of the fact that a mandatory life sentence for murder had hitherto been strongly supported by Conservatives - and pro-Conservative newspapers - as part of their tough stance on law and order), so that a sentence other than life imprisonment could be imposed in certain circumstances. To this end, Hague pledged that the next Conservative government would amend the law, so that the state will be on the side of people who protect their homes and families against criminals', ${ }^{7}$ a pledge reiterated by the Shadow Home Secretary, Ann Widdecombe, when she informed delegates at the Conservatives' 2000 conference that it 'cannot be common sense to arrest the householder instead of the burglar'. Consequently, in the 2001 election campaign, the Conservatives promised a Victims First initiative, which would include a new legal right to 'self-defence' for victims of crime. 
The Conservative Party also sought to link the plight of Tony Martin to the problems of the countryside in general, alleging that crime in rural areas was another manifestation of New Labour's neglect of rural issues and citizens (see below).

Meanwhile, in citing drug abuse as a major factor underpinning much criminal activity in Britain, Widdecombe announced (with Hague's approval), at the 2000 conference, that she favoured a 'zero tolerance' policy towards the possession of drugs - any drugs - which would entail an automatic $£ 100$ fine in the first instance, with an automatic court appearance for a second offence. ${ }^{8}$ Having previously derided Blair's suggestion that drunken yobs should be subject to a $£ 100$ on-the-spot fine (or escorted to the nearest cashpoint machine), Widdecombe was taken aback by the rather lukewarm response of the police to such a policy. Rather more damaging, though, were the subsequent announcements by several Shadow Cabinet colleagues that they themselves had imbibed soft drugs when younger or at university, yet none of them had progressed to hard drugs or crime. Not surprisingly, perhaps, the policy proposal was rapidly retracted for reconsideration.

\section{The family and sexual politics}

Hague's Conservatives were afforded ample opportunity to re-emphasise their self-appointed role as the party of the family in the context of New Labour's commitment to 'gay rights', and the Blair government's abolition of the married person's tax allowance in April 2000.

With regard to the issue of 'gay rights', Hague's initial intimation that the Conservative Party ought to become more 'socially inclusive' and less prescriptive about people's lifestyles was not reflected in the Division Lobbies when the Blair government sought - via the 1998 Crime and Disorder Bill - to reduce the age of consent for gay sex to sixteen, thereby ensuring legal equality with heterosexuals. Although Hague himself had previously supported such a change in the law in 1994, only sixteen Conservative MPs voted in favour of equalisation four years later, the legislation subsequently being obstructed in the House of Lords, with the Conservative Baroness Young denouncing it as a 'paedophile's charter'.

That Hague's 'socially inclusive' Conservatism was a short-lived phenomenon, and one which was not widely or enthusiastically endorsed by many other Conservative MPs, was subsequently indicated by the party's staunch opposition to the government's attempt (via the 1999 Local Government Bill) at repealing Section 28 of the 1988 Local Government Act, which prohibited the 'promotion of homosexuality' in schools. The Conservative leadership imposed a three-line whip on its peers - the Bill having been introduced in the House of Lords, rather than the Commons - to oppose repeal of Section 28, and this opposition was maintained in spite of various 
modifications and measures proposed by Labour ministers to assuage the objections of the Conservatives. Faced with implacable opposition from Conservative peers in the Lords (this being prior to the removal of the majority of hereditary peers), and unable to invoke the 1949 Parliament Act - which does not apply to Bills introduced in the House of Lords - the government was obliged to abandon its initial attempts at repealing Section 28, although New Labour remained formally committed to such reform. ${ }^{9}$

For Hague's Conservative Party, however, the successful opposition to repeal of Section 28 could be depicted as a victory both for 'common sense', and for traditional Conservatism, with its strong emphasis on the importance of marriage, as well as the conviction that sex education in schools ought to be more morally prescriptive. However, the party's stance on 'gay rights' also resulted in the defections to New Labour of Shaun Woodward (who had been sacked from the Shadow Frontbench because of his refusal to support the party's stance in opposing repeal of Section 28), and a wealthy Conservative businessman, Ivor Massow, both of whom alluded to the 'bigotry' still prevalent in much of the Party, whilst Marc Cranfield-Adams, a Conservative 'gay rights' campaigner, warned the leadership that: 'Society has moved on. The Conservative Party must move on too.' 10

This reinvigorated emphasis on the centrality of marriage and the 'normal' family was further emphasised through key speeches by Hague, and by the party's response to the government's abolition of the married couples' tax allowance. Having successfully resisted legislation which would allegedly have permitted the 'promotion of homosexuality' in schools via sex education lessons, the Conservatives returned to a theme from Major's era, namely the innate superiority of (married) couples over single parents, particularly with regard to child-rearing. Whilst insisting that the Conservative Party was not seeking to demonise lone parents - a more contrite Portillo had even made a speech shortly after losing his Enfield and Southgate seat in 1997, acknowledging that some single parents did an excellent job in raising their children in very difficult circumstances - various speeches made by senior Conservatives towards the end of the 1990 s indicated that most of them continued to believe strongly in the moral superiority and social necessity of marriage, and joint parental responsibility for raising children.

Indeed, in a speech to the Social Market Foundation in January 1998, Hague intimated that the Conservatives had not done enough to assist traditional families during their eighteen years in office. ${ }^{11}$ Although he insisted that the Conservative Party had to become more tolerant of personal and sexual relationships other than marriage, he remained convinced that marriage was the best institutional arrangement for raising children, to the extent that divorce was often more traumatic for children than being brought up by parents who were no longer happily married. Furthermore, Hague 
claimed that whilst 'People who cohabit presumably have taken a legitimate decision not to marry ... we should respect the decision of people who wish to cohabit by not extending to them the full panoply of marriage law.' In other words, cohabiting couples should not be entitled to the same pension rights, or rights pertaining to division of property, as married couples. Whilst cohabitation was a matter for the individuals concerned, Hague believed that the state was entitled to make clear its preference for marriage by offering married couples tax allowances, particularly in respect of their children. Clearly, greater acceptance of alternatives lifestyles and sexual relationships did not mean moral neutrality or indifference.

Later the same year, in his speech to the party's 1998 conference, Hague alluded to the apparent link between the welfare state and family disintegration, when he insisted on the need for 'welfare reform that encourages families to stay together and doesn't discriminate against marriage'. To this end, Hague pledged that the Conservative Party would 'develop policies on welfare reform which strengthen family responsibility and support for the institution of marriage'.

The Conservatives thus condemned the government's April 2000 abolition of the married couples' tax allowance, which Hague deemed 'vital to a stable, healthy society', on the grounds that children were 'nearly always' best raised by a married couple. Restoration of this tax allowance henceforth became a clear commitment of the Conservative Party, and was reiterated in the 2001 election manifesto.

\section{Welfare reform and pensions}

Having spent eighteen years in office seeking to reform and curb Britain's welfare state, there was no diminution by the Conservatives in their efforts to detect fraud and identify those who constituted an 'undeserving poor'. Again, however, their task was rendered more difficult by the government's own tougher stance against those who abused the welfare state, and New Labour's 'third way' insistence that rights had to be matched by reciprocal responsibilities; the unemployed could no longer expect 'something for nothing' under a Labour government, with Blair insisting that welfare provision should be about providing 'a hand-up, not a hand-out'.

In this context, the Conservatives sought to outflank the government by promising even stronger measures to combat welfare abuse and the workshy. Hague promised delegates at the 1999 Conservative conference that when the party was next in office, 'any unemployed person who can work, and who is offered a job, either takes that job or loses their unemployment benefits'. Furthermore, Hague pledged that a system of payment-by-results would be imposed on job centres, thus making clear that they 'are not there to pay people benefits for doing nothing'. 
Meanwhile, for many Conservatives, single parents continued to straddle the boundary between revival of traditional (family) morality and retrenchment of the welfare state, with the party's social security spokesperson, David Willetts, unveiling proposals for further tightening-up eligibility criteria for lone parents. In a 1999 speech to the Social Market Foundation, Willetts announced that under a Conservative government, once their only or youngest child had reached eleven years of age, single parents would be given thirteen weeks in which to find paid employment, after which their benefit would be reduced (although they would continue to receive social security payments for their children). This, Willetts claimed, would ensure that rather than receiving welfare benefits 'simply by virtue of not having an income and being a single parent', lone parents would 'instead be expected ... to be actively seeking work - seeking the sorts of jobs which their married counterparts are doing'. ${ }^{12}$

The Conservatives might have expected more success on the issue of old age pensions, partly because of the traditionally higher levels of support the party attracted amongst the elderly, and also because of the outcry which followed the government's announcement of a derisory $80 \mathrm{p}$ increase in the state pension for April 2000 (the rationale being that this was in line with the then very low rate of inflation, to which pensions and other welfare benefits were generally linked - another policy which New Labour inherited from previous Conservative governments).

Apart from condemning the government over this insultingly low increase in the state pension, the Conservatives also criticised the introduction of free TV licences for the over seventy-fives, along with the system of one-off Christmas bonuses and winter fuel allowances, claiming that these were another manifestation of New Labour's 'nanny state' tendencies, with pensioners being told that certain payments were for specific purposes only. Against this, Willetts, argued that these 'special payments' should be consolidated into an overall increase in the state retirement pension, whereupon pensioners would be able to exercise their own choice and individual responsibility in deciding how to spend the money.

However, when Chancellor Gordon Brown subsequently announced a significant increase in the state pension - well above the rate of inflation the Conservatives responded by suggesting that pensioners should be permitted to decide whether they wanted to have a higher 'consolidated' pension, or to retain the various 'one off' payments and bonuses. What was perhaps not fully appreciated, though, was that this would yield two parallel systems of state retirement pensions, leading to considerable administrative complexities for a Conservative Party committed to cutting red tape. More important, however, was that in spite of the outcry over the $80 \mathrm{p}$ increase in the state pension in 2000, Labour still led the Conservatives in the 2001 election campaign, when an ICM poll asked voters which of the parties had the best 
policies on pensions, although this may have owed something to Brown's contrition in increasing pensions by $£ 5$ per week in the April 2001 budget. Furthermore, in the general election itself, support for the Conservative Party amongst the sixty-five plus age cohort declined slightly, from 44 per cent in 1997 (having been 53 per cent back in 1983) to 42 per cent in 2001, whilst amongst the fifty-five to sixty-four age group (the next generation of pensioners, in effect), Labour led the Conservatives by 40 per cent to 34 per cent.

\section{Asylum seekers}

Faced with consistently low opinion poll ratings (the false dawn of early autumn 2000 notwithstanding), one of the few policy areas where Hague's Conservatives believed they could garner significant support, and thereby force the Blair government onto the defensive, was that of asylum seekers, or, more particularly, 'bogus' asylum seekers. Just as ministers in the Major government had sought to posit a distinction between legitimate refugees and mere 'economic migrants', so too did the Conservatives after 1997 draw a distinction between genuine asylum seekers literally fleeing for their lives from tyrannical political regimes, and 'bogus asylum seekers' who were deemed to be illegally entering Britain in search of a more prosperous lifestyle or 'easy' welfare benefits. In spite of this distinction, however, the phrase 'bogus asylum seekers' was used so routinely that many people instinctively viewed asylum seekers as 'bogus' per se.

From the Conservatives' perspective, highlighting the alleged problem of 'bogus asylum seekers' provided scope for connecting a number of themes which were traditionally advantageous to the party. Firstly, the party could appeal - however vehemently Hague might deny it - to racist and xenophobic sentiments amongst the least-educated sections of British society, by identifying the 'alien other' or 'outsiders' who were threatening to overwhelm the country. Secondly, but following directly on from this, the Conservatives invoked the numbers game, by claiming that 'bogus asylum seekers' were 'flooding' Britain, so great was the increase in their numbers under the Blair government - official figures indicating that the number of asylum seekers had increased from 29,640 in 1997 to 76,035 in 2001 - thereby reviving echoes of Margaret Thatcher's notorious 1978 'swamping' speech. Thirdly, but again, following on from this point, Hague and many of his colleagues directly blamed the government, insisting that it had rendered Britain 'a soft touch' due to its inability or unwillingness to address the issue properly. Fourthly, some Conservatives alluded to the apparent drain on resources, either in terms of welfare payments, or the costs incurred by some local authorities in having to house asylum seekers whilst their applications were being considered. Fifthly, there was occasional criticism of the Home 
Office for its apparent tardiness in processing claims for asylum, and the delay in reaching decisions. Finally, there were occasional attempts at linking the issue to Euro-scepticism, on the grounds that other European countries (France especially) ought either to be more vigilant in apprehending 'bogus asylum seekers' en route to Britain, or should themselves be accepting more of them, so that they did not target Britain in such apparently large numbers.

The Conservatives' response was to invoke the phrase 'a safe haven, not a soft touch', claiming that a Conservative government would deal sympathetically with genuine asylum seekers, but severely with those deemed 'bogus'. What was also urgently required, the Conservatives insisted, was a much more swift and efficient procedure for processing applications for asylum, thereby reducing the growing backlog of cases, whilst ensuring that those whose applications were rejected could be deported much more quickly (thereby also alleviating the growing burden on taxpayers and local authorities). Meanwhile, whilst their applications were being processed, the Conservative Party suggested that asylum seekers should be detained in secure 'reception centres'.

\section{Rural affairs}

Britain's status as an advanced industrial society (now post-industrial, many would claim) has ensured that, in contrast to some other European countries, an urban-rural cleavage had never been particularly prominent or politically significant during the twentieth century, even though the shires have generally been Conservative heartlands. However, from 1997 onwards, 'rural politics' did become a more discernible issue, and one onwhich the Conservatives sought to capitalise under Hague's leadership.

In recent years, Britain's rural communities have faced a number of problems, most notably: the continued decline of the farming industry (exacerbated by the BSE crisis of the mid-1990s, and the foot-and-mouth epidemic in the spring of 2001); the closure of rural schools and post offices (previously endorsed by many Conservatives on the grounds of cost-effectiveness and lack of economic viability); the paucity of public transport in rural areas (particularly in the wake of deregulation or privatisation of transport, whereupon many rural routes were deemed not commercially viable'); the high cost of housing in many villages, which many younger people raised in them cannot afford, in which case they often move away, leaving the villages either to atrophy, or be 'colonised' by former urban dwellers and 'townies' buying second homes or retiring to the countryside.

Although these trends had emerged or accelerated under the Major governments during the 1990s, Hague's Conservative Party sought to claim that the plight of Britain's countryside was largely the responsibility of the 
Blair government, constituting as it allegedly did a 'metropolitan elite' which was ignorant of, or indifferent to, the vicissitudes of village life in rural areas of Britain. Having spent two decades denouncing subsidies to inefficient or outdated industries, condemning the demands of producer interests, insisting on the need for flexibility and adaptation to change, and extolling the virtues of self-help, the Conservatives suddenly rediscovered the virtues of government intervention and investment, at least in relation to the farming industry and protection of rural communities. Compared to the relentless neoliberalism and individualism of the 1980s and most of the 1990s, it was a truly remarkable U-turn.

Another apparent U-turn manifested itself in the Conservatives' defence of 'green belts' against further urban sprawl. Having itself presided over extensive 'out-of-town' housing developments during the 1980 s and much of the 1990s, the post-1997 Conservative Party demanded that two-thirds of new houses should henceforth be built on 'brownfield' sites (such as derelict land) in urban areas, thereby simultaneously reviving inner-city districts whilst protecting the countryside from further urban encroachment.

What really crystallised ruralism as a political issue, though, was the Blair government's avowed intention to outlaw fox-hunting. Indeed, a Private Members' Bill introduced in the 1997-98 parliamentary session, to prohibit hunting with hounds, prompted the formation of the Countryside Alliance, which held a high-profile rally in London in March 1998. Although this body purported to be concerned about a wide range of rural problems, it was clear that defence of fox-hunting was its primary motivation, with other issues conjoined in order to attract wider support.

Furthermore, whilst the Countryside Alliance purported to be non-political (and even ostentatiously highlighted a few Labour politicians amongst its ranks), it was clear that it shared a very close affinity with the Conservatives, with the latter echoing many of the Alliance's grievances and attacks on the government. With regard to New Labour's desire to ban fox-hunting, Conservatives (and the Countryside Alliance) deployed various arguments, most notably that it was an issue of individual liberty, that a ban would lead to further job losses in rural areas, and that fox-hunting was a traditional and cultural component of rural life in Britain - something which was beyond the comprehension of a urban, metropolitan Labour government. It was also occasionally claimed that thousands of hounds would have to be destroyed if fox-hunting was outlawed. For many Conservatives, the government's antipathy to blood-sports was a manifestation of a rather 'Old Labour' class warfare, on the grounds that fox-hunting was perceived to be enjoyed primarily by wealthy landowners and squires, rather than rural dwellers of all social and occupational backgrounds.

That the Blair government was seeking to outlaw fox-hunting, whilst also infuriating many landowners by legislating for a statutory 'right to roam' 
across their land, at a time when the countryside was already in crisis, was cited by the Conservatives as evidence of the Labour Party's contempt for rural people and their traditional way of life. New Labour, it seemed, was unable or unwilling to see beyond the bistros and wine-bars of Islington, and with Hague himself representing a market town in rural North Yorkshire, the Conservatives clearly aligned themselves with the 'simple folk' of the shires against Blair's 'liberal, metropolitan, urban, elite’.

\section{Conclusion}

Hague's Conservative Party faced a particularly difficult task in developing a coherent and popular raft of policies in opposition after the 1997 election defeat. The party's uncertainty and lack of agreement over the most appropriate ideological response (discussed in the previous chapter) to New Labour's landslide victory at the polls was itself a major inhibition in developing consistent policies. Hence the Conservative Party oscillated between advocacy of more tolerant and 'socially inclusive' policies at some junctures before resorting to more authoritarian populist measures at others. This inconsistency was itself a consequence not merely of the long-standing ideological divisions in the parliamentary party between Thatcherites and remnants of One Nation Toryism, but of the apparent recantation of former Thatcherites like Lilley and Portillo, who sought to reposition themselves away from the right of the party, particularly on social issues.

The Conservatives' difficulties in developing a coherent and consistent set of policies were further exacerbated by the traditional problem facing a party which has just lost office, namely the time needed to reconsider and regroup. To embrace new policies too quickly would not only increase the likelihood of ill-judged or incoherent measures being adopted, but would also appear to many voters as blatant opportunism. It would either imply that the party was prepared to say virtually anything in order to return to power at the earliest possible opportunity, with scant regard to its political principles, or it would lead sceptical voters to enquire why the new policies had not been considered or implemented whilst the party was still in office, in place of the unpopular policies which had presaged the election defeat. Furthermore, if policies were hastily adopted which looked like proving popular, then they were likely to be appropriated by the government, which would then take the political credit if they were successful, a fact recognised by Lilley when he was allocated responsibility for overseeing a review of Conservative policies in June 1998. ${ }^{13}$

A further problem facing the Conservative Party after May 1997 directly relates to the success of the Labour Party in repositioning itself during its eighteen years in opposition. On the basis that much of the British electorate preferred or trusted the Conservatives' economic policies - at least up until 
September 1992 - whilst liking Labour's social policies, New Labour sought to meld the two, so that nationalisation and higher income taxes were jettisoned, and a more business-friendly stance adopted, whilst commitments remained to social justice, reviving public services and eradicating poverty the much-vaunted 'third way'. Given the range of economic principles and policies which the Blair government inherited, maintained and even developed further, the Conservatives found it difficult to level consistent or convincing criticisms against the government, particularly as these might be construed as criticisms against some of the measures that Conservative ministers themselves implemented prior to 1997. On the other hand, Conservative criticisms pertaining to the state of public services under the Blair government merely served to remind voters of how education, health and public transport had been allowed to deteriorate for eighteen years in the first place. Similarly, when Conservatives denounced the government for the mountain of red tape and bureaucracy in schools, universities and hospitals, Labour ministers could readily point out that these were invariably associated with reforms - internal markets, quality audits, etc - introduced by the Thatcher and Major governments.

Finally, and perhaps most importantly, the post-1997 Conservative Party has found it difficult to come to terms with the world as it is today (even though it played a notable part in shaping it when in office) and thereby to formulate an appropriate range of policies in response. During the 1990s, the excesses of the unfettered free market and the relentless drive for more competitiveness proved profoundly destabilising for much of the British middle and professional classes, who had previously looked to the Conservative Party to provide them with security and stability. ${ }^{14}$ The 'labour market flexibility' which Conservative ministers extolled so enthusiastically was instead experienced by millions of people as increased job insecurity, fixed-term contracts and longer working-hours. Yet in remaining wedded to the alleged virtues of globalisation and the free market, and thus denouncing the meddling 'nanny state', the Conservative Party since 1997 has remained unable or unwilling to address the problems of job insecurity and excessive working hours, which themselves appear to be having an increasingly damaging impact on people's health, whilst also being inimical to family life.

An indication of the problems facing the post-1997 Conservative Party in developing new policies was indicated when Hague announced a 'Listening to Britain' exercise in the summer of 1998, involving Shadow Ministers attending up to 150 meetings throughout the country, attended by 40,000 people, with a view to discerning what ordinary citizens were thinking and asking for vis-à-vis a whole range of policy issues. In announcing this consultation exercise, Hague claimed that apart from the party's stance on the single European currency, every previous Conservative policy was 
subject to review and potential revision. However, he was also emphatic that Conservative principles were non-negotiable, so that the party's commitment to a low-tax, private enterprise economy remained inviolate, as did its belief in the importance of the family, the constitution, and the nation state. ${ }^{15}$ It immediately became apparent, therefore, that the scope for new policies was actually rather limited, and that many existing commitments would not be ditched after all.

The 'findings' of the 'Listening to Britain' exercise were published a year later in a document of the same name, by which time Hague was proclaiming a 'Common Sense Revolution' to provide the basis of Conservative policies for the next general election. What was pledged (via an eponymous forty-two page document) was a series of policy proposals - half populist, half prosaic - which variously promised empowerment for families and 'the community' against 'the nanny state', a reduction in the overall tax burden (albeit during the lifetime of a Parliament), and measures to create a more secure society, whilst defending Britain's interests vis-à-vis the European Union. These pledges were reiterated in 2000 in yet another policy document (albeit more brief, at twenty-nine pages), Believing in Britain.

Yet Hague's Conservative Party found that neither the more 'socially inclusive' stance of the early period in opposition - a stance which continued to be urged by former Thatcherites like Portillo and Lilley - nor a reversion to a more populist stance during the latter period, elicited a discernible or durable increase in popularity. Indeed, in spite of the Blair government's arrogance, obsession with 'spin' and self-confessed failure to 'deliver', the Conservatives proved unable to regain public support, beyond their core 30 to 32 per cent.

Hague and his senior colleagues were in an unenviable position throughout the Conservatives' period in opposition. Adopting a more 'socially inclusive' and 'social liberal' stance, in order to challenge New Labour for the centre One Nation ground, incurred the wrath of the homophobes, xenophobes and petit-bourgeois curtain-twitchers on the party's right, who still yearned for the social authoritarianism and moral absolutism of Thatcherism. It has always been an irony that those Conservatives most critical of the drab grey conformity which socialism would allegedly impose - 'they'd make us all the same' - are invariably the very Conservatives most intolerant of any social group which is different to the majority, and is thus deemed deviant or dangerous for not conforming. Such Conservatives call for an increase in individual liberty and less government interference, yet then instinctively mutter it shouldn't be allowed ... the government ought to put a stop to it' when confronted by a lifestyle or socio-cultural minority of which they disapprove - 'why can't these people just be like everybody else?'. Yet, on the other hand, when Hague's Conservatives retreated to right-wing authoritarian populism to bolster the party's 'core support', it 
found itself being denounced for succumbing to extremism, and of being out-of-touch with mainstream centrist opinion, even though on issues like retaining Section 28, anxiety about asylum seekers and opposing the euro, the Conservatives' stance broadly reflected public opinion. Yet this did not yield any notable increase in electoral support, largely because on most issues - and especially the most salient ones - the government retained a lead over the Conservatives in terms of trust and competence. Even in policy areas where New Labour had evidently 'failed to deliver', it was still generally preferred to the Conservatives, and deemed more likely to deliver if granted a second term. By contrast, the Conservatives found that on a range of policies, they were either disliked, or simply not trusted, particularly on those pertaining to the public services, although even on their traditional trump card, the economy, they trailed New Labour by a considerable margin.

The consequent election defeat in June 2001, when the Conservatives gained just one additional seat overall, means that Hague's successor, Iain Duncan Smith, will have to grapple with all of the same policy issues, whilst simultaneously hoping either that the Blair government's 'luck' will run out before the next general election, or that the electorate will tire of New Labour's 'spin' and continued failure (perceived or proven) to 'deliver' on asylum, crime, education, health and transport, even if the economy remains relatively robust.

\section{Notes}

1 T. Baldwin, 'The polished prose that is written by many and read by few', The Times, 24 February 2001.

2 See J. Bush, 'Bare-faced cheek of Brown's critics', The Times, 28 October 1998.

3 G. Jones, 'Confident Tory leader enters enemy territory with tax weapon', Daily Telegraph, 11 July 2000.

4 A. Sparrow and G. Jones', 'Tories "aspire” to cut taxes beyond the £8bn promise', Daily Telegraph, 15 May 2001.

5 G. Jones, 'Firms must keep the fuel flowing', Daily Telegraph, 18 September 2000.

6 'The Stephen Lawrence Inquiry Report' ['the Macpherson Report'] (London, HMSO, 1999) Cm 4262-I.

7 N. Watt, 'Hague joins outcry over jailed farmer', Guardian, 26 April 2000.

8 G. Jones, 'Tory crackdown on cannabis', Daily Telegraph, 4 October 2000.

9 For a detailed analysis, see M. Waites, 'Regulation of sexuality: age of consent, Section 28 and sex education', Parliamentary Affairs, 54:3 (2001).

10 A. Pierce, 'Threat of revolt forces Tory U-turn on gays', The Times, 11 December 1999.

11 See J. Sherman, 'Hague calls for tax aid to boost family values', The Times, 30 January 1998.

12 See A. Frean, 'Conservatives plan jobs deadline for single parents', The Times, 23 November 1999.

13 D. Butler and D. Kavanagh, The British General Election of 2001 (London, Palgrave, 2002), p. 48. 
14 See P. Dorey, 'Despair and disillusion abound: the Major Premiership in perspective', in P. Dorey (ed.), The Major Premiership: Politics and Policies under John Major (London, Palgrave, 1999), pp. 218-49, and J. Gray, 'Conservatism R.I.P.', in J. Gray and D. Willetts, Is Conservatism Dead? (London, Social Market Foundation, 1997).

15 A. Pierce, 'Tories go on tour as Hague pledges wholesale changes', The Times, 15 July 1998. 